\title{
Role of Nano-Goethite in Controlling U(VI) Sorption-Desorption in Subsurface Soil
}

\author{
Hun Bok Jung ${ }^{1,2} *$, Huifang $\mathrm{Xu}^{1}$, Hiromi Konishi ${ }^{1}$, and Eric E. Roden ${ }^{1}$ \\ ${ }^{1}$ Department of Geoscience, University of Wisconsin-Madison \\ ${ }^{2}$ Department of Geoscience and Geography, New Jersey City University
}

\section{Corresponding Author}

Hun Bok Jung

Department of Geoscience and Geography, New Jersey City University 2039 Kennedy

Boulevard, Jersey City, New Jersey 07305

Phone: 201-200-3161; Fax: 201-200-2298

E-mail: hjung@njcu.edu 


\begin{abstract}
Iron oxide nanoparticles in natural soils and sediments can be nanoporous due to the aggregation of nanoparticles. Nanopores can greatly affect the sorption-desorption as well as reductionoxidation behavior of U(VI) because of their high internal surface area and nanopore confinement effects. Batch U(VI) sorption-desorption experiments were conducted to understand the role of nano-goethite in controlling U(VI) sorption-desorption behavior in saprolite subsoil from Oak Ridge Field Research Center (ORFRC), Tennessee, a premier field research site for environmental remediation. The subsoil samples from $\sim 6.5-8.5 \mathrm{~m}$ depth were nearly homogeneous in mineral composition (quartz, illite and smectite) and particle size distribution. The subsoil samples were characterized by a range of dithionite-citrate-bicarbonate (DCB) extractable $\mathrm{Fe}(\mathrm{III})$ oxide content $(127-404 \mu \mathrm{M} / \mathrm{g})$, BET surface area $\left(25-38 \mathrm{~m}^{2} / \mathrm{g}\right)$, and nanoporosity (pore size $<10 \mathrm{~nm} ; 16-30 \mu \mathrm{L} / \mathrm{g}$ ). Transmission electron microscopy (TEM) imaging and X-ray energy dispersive spectroscopy (EDS) analyses revealed that aggregated goethite nano-crystals were poorly crystalline and nanoporous, and U(VI) sorption was dominantly associated with those nanoporous goethite aggregates rather than clay minerals. $\mathrm{U}(\mathrm{VI})$ sorption to the saprolite subsoils at circumneutral $\mathrm{pH}$ increased with higher amount of nanoporous goethite in the presence of a range of $\mathrm{Ca}^{2+}$ and $\mathrm{HCO}_{3}{ }^{-}$. Sequential extraction of U(VI) pre-sorbed to saprolite subsoils with $\mathrm{NaHCO}_{3}(1,10$, and $100 \mathrm{mM}$ ) exhibited more resistant $\mathrm{U}(\mathrm{VI})$ desorption from soils containing higher amount of nanoporous goethite. This study suggests that nano-crystalline goethite with nanoporous structure may exert a significant role in controlling the mobility and transport of $U(V I)$ in subsurface environment where nanoporous minerals are ubiquitous and abundant.
\end{abstract}

Keywords: Uranium, Nanopores, Goethite, Sorption, Saprolite 


\section{Introduction}

Subsurface soil/sediment and groundwater have been contaminated with uranium at numerous uranium mining and nuclear weapons manufacturing sites, posing a human health and environmental threat (Lottermoser and Ashley, 2005; McKinley et al., 2007; Neiva et al., 2014). In natural environments, uranium occurs mainly in the form of U(IV) and U(VI) depending on redox state (Langmuir, 1997). $\mathrm{U}(\mathrm{VI})$ is the dominant species in oxic aquifers, and its mobility is governed by sorption-desorption processes. The mobility of U(VI) increases with U(VI) complexation by carbonate species and calcium (Dong et al., 2005; Fox et al., 2006; Wazne et al., 2003), which are common chemical components in groundwater.

Uranium mobility and transport have been investigated by numerous batch and column experiments using synthetic Fe or Al oxides, as well as natural sediments and soils (Barnett et al., 2002; Barnett et al., 2000; Davis et al., 2004; Hsi and Langmuir, 1985; Sylwester et al., 2000). However, mechanistic understanding of uranium sorption-desorption behavior in subsurface environments is complicated by the chemical and physical heterogeneity of subsurface materials. Thus, results from laboratory sorption experiments using pure synthetic minerals may not properly represent the chemical reactions occurring in natural systems. For instance, although nanopores are ubiquitous in porous geologic media and provide the most reactive surface area, the role of nanopores in controlling the mobility of inorganic and organic contaminants remains poorly understood (Hochella, 2008; Wang et al., 2003) because most of laboratory batch or column sorption experiments have been conducted using non-nanoporous materials. A strong time-dependence of sorption and non-reversible desorption behavior, as well as partial and incomplete redox reaction that are frequently observed in natural soil or sediment, have been attributed to the effect of nanopores or micropores (Hochella, 2008; Jeon et al., 2004; 
Pignatello and Xing, 1996; van Beinum et al., 2005). Ferric iron oxides (e.g., ferrihydrite, goethite, and hematite), which are widely thought to be the most important sorbents for U(VI) under circumneutral $\mathrm{pH}$, are likely nanoporous in natural sediments/soils due to the aggregation of nanoparticles (Banfield et al., 2000; Gilbert et al., 2009; van der Zee et al., 2003). Nanopores can greatly affect the sorption-desorption or reduction-oxidation behavior of U(VI) because of their high internal surface area and nanopore confinement effects (Jung et al., 2012; Senapati and Chandra, 2001; Wang, 2014; Wang et al., 2003).

Although numerous studies have investigated the role of Fe(III) oxides in controlling U(VI) sorption or desorption using synthetic minerals or natural soil/sediments (Barnett et al., 2002; Barnett et al., 2000; Curtis et al., 2004; Fox et al., 2006; Hsi and Langmuir, 1985; Kohler et al., 2004; Waite et al., 1994), few studies have focused on the mechanistic role of Fe(III) oxide nanoparticles in natural subsurface soil/sediment. In order to understand the role of natural Fe(III) oxide nanoparticles in regulating U(VI) sorption-desorption behavior in subsurface soil, we conducted batch sorption and desorption experiments with natural saprolite subsoils from Oak Ridge Field Research Center (ORFRC), which contained various amounts of nano-goethite. Nanoporous structure of nano-goethite in the saprolite subsoils was investigated by high resolution transmission electron microscopy (TEM) imaging.

\section{Material and methods}

\subsection{Samples Preparation}

Subsurface soil cores ( $5 \mathrm{~cm}$ diameter) were collected at the Area 2 site of Oak Ridge Field Research Center (ORFRC), Tennessee as previously described (Moon et al., 2006). The soil core tubes were sealed with plastic caps immediately after sample collection and stored at $4^{\circ} \mathrm{C}$. The 
ORFRC was established within the Y-12 National Security Complex area on the Department of Energy's Oak Ridge Reservation in Oak Ridge, TN to serve as a premier field research site for environmental remediation (Moon et al., 2006).

Materials were retrieved from ca. 90-cm lengths of native saprolite at 6.5-9 m depth below the ground surface. The core sections were air-dried, sieved through a $2 \mathrm{~mm}$ sieve, and thoroughly homogenized. A portion of sample was extracted with $10 \%$ nitric acid (1.6 N) (Fisher, trace metal grade) for 2 days to determine total solid phase $\mathrm{U}$, and with the dithionitecitrate-bicarbonate (DCB) to determine the amount of Fe(III) oxides (e.g., goethite, ferrihydrite) (Jackson, 1986). For the DCB extraction, $2.5 \mathrm{~g}$ of the sieved saprolite soil was reacted with 20 $\mathrm{mL}$ of $0.3 \mathrm{M}$ sodium citrate solution, $2.5 \mathrm{~mL}$ of $1 \mathrm{M}$ sodium bicarbonate solution and $0.5 \mathrm{~g}$ sodium dithionite at $80{ }^{\circ} \mathrm{C}$ for 15 minutes with vigorous stirring. After the supernatant was collected, the same extraction was repeated. The DCB extractable Fe is the sum of the first and second extractions.

Based on DCB extractable Fe, three samples (GP-4-5-00, GP-4-4-25, and GP-3-5-00 at 6.5$8.5 \mathrm{~m}$ depth) containing background levels of $\mathrm{U}\left(<0.01 \mu \mathrm{M} / \mathrm{g}\right.$ by $10 \% \mathrm{HNO}_{3}$ for 2 days $)$ and a range of Fe(III) oxide content $(7138,11161$, and $22582 \mathrm{mg} / \mathrm{kg} \mathrm{Fe})$ were selected, and will be referred to as low Fe(III) soil, medium Fe(III) soil, and high Fe(III) soil, respectively (Table 1). Specific surface area and pore size distribution were determined using a surface area and pore size analyzer (NOVA e4200, Quantachrome Instruments) by BET (Brunauer-Emmett-Teller) method and BJH (Barrett-Joyner-Halenda) method, respectively. The standard reference material (Quantachrome Instruments; $108 \mathrm{~m}^{2} / \mathrm{g}$ ) confirmed that the analytical error is less than $\pm 5 \%$.

\subsection{X-ray diffraction (XRD) and transmission electron microscopy (TEM) analysis}


X-ray diffraction analyses were carried out using a Rigaku Rapid II X-ray diffraction system with a 2-D image plate (Mo Ka radiation). The two-dimensional images were integrated to produce conventional 20-I patterns using Rigaku's 2DP software. Mineral identification was conducted using JADE software (Materials Data Inc., Livermore, CA) with a database published by the Joint Committee on Powder Diffraction Standards (International Center for Diffraction Data, Newtown Square, PA). TEM and SAED (Selected Area Electron Diffraction) measurements were carried out using a FEI Titan 80-200 FEG-TEM/STEM microscope equipped with an X-ray EDS (Energy Dispersive Spectroscopy) analyzer and Gatan Image Filtering (GIF) system to provide a high resolution image of goethite nano-crystals. All the TEM samples were prepared by dropping solid suspension drops onto holey carbon-coated TEM copper grids and dried in air. After reacting saprolite subsoil samples $(0.2 \mathrm{~g})$ with $0.1 \mathrm{M} \mathrm{NaNO}_{3}$ solution containing $150 \mu \mathrm{M} \mathrm{U}(\mathrm{VI})$ and $1 \mathrm{mM} \mathrm{NaHCO}$ at $\mathrm{pH} 6.8$ buffered by $10 \mathrm{mM}$ PIPES (1,4-piperazinediethanesulfonic acid) for 1 week, the U(VI) sorbed on goethite nanoparticles and clays was analyzed by TEM-EDS.

\subsection{Batch Sorption-Desorption Experiments}

One gram of dry soil was placed in a $15 \mathrm{~mL}$ plastic centrifuge tube (Fisher Scientific), and 10 $\mathrm{mL}$ of a solution containing $\mathrm{U}(\mathrm{VI})$-acetate $(50-95 \mu \mathrm{M}), \mathrm{NaHCO}_{3}(0.1-5 \mathrm{mM})$, and $\mathrm{Ca}\left(\mathrm{NO}_{3}\right)_{2}(0-$ $10 \mathrm{mM}$ ) was added. $\mathrm{Ca}^{2+}$ and $\mathrm{HCO}_{3}{ }^{-}$have a significant impact on the aqueous speciation of $\mathrm{U}(\mathrm{VI})$, and consequently, on the sorption and mobility of $\mathrm{U}(\mathrm{VI})$ in aquifers because of the formation of uranyl calcium carbonato and uranyl carbonato species (Fox et al., 2006). The

concentration range of $\mathrm{Ca}^{2+}$ and $\mathrm{HCO}_{3}{ }^{-}$were selected to represent typical fresh groundwater compositions. The solution $\mathrm{pH}$ was initially adjusted to 6.3 by adding $0.1 \mathrm{~N} \mathrm{HNO}_{3}$ or $0.1 \mathrm{~N}$ 
$\mathrm{NaOH}$ and using a $\mathrm{pH}$ meter (Accumet XL20, Fisher Scientific). For sorption kinetics experiments, the tubes were shaken at $250 \mathrm{rpm}$ for 20 minutes to 2 days in the presence of 95 $\mu \mathrm{M} \mathrm{U}(\mathrm{VI}), 1 \mathrm{mM} \mathrm{\textrm {HCO } _ { 3 }}{ }^{-}$and $0-10 \mathrm{mM} \mathrm{Ca}^{2+}$. Additional sorption kinetics experiment was conducted by reacting $50 \mu \mathrm{M} \mathrm{U}(\mathrm{VI})$ with the soil samples $(1 \mathrm{~g})$ in $0.1 \mathrm{M} \mathrm{NaNO}_{3}$ solution (10 $\mathrm{mL}$ ) containing $2.5 \mathrm{mM} \mathrm{Ca}^{2+}$ and $5 \mathrm{mM} \mathrm{HCO}_{3}{ }^{-}$at equilibrium $\mathrm{pH}$ of $\sim 6.5-7.0$ for 2 weeks. For sorption equilibrium experiments, the tubes were shaken at $250 \mathrm{rpm}$ for 2 days in the presence of $90 \mu \mathrm{M} \mathrm{U}(\mathrm{VI})$ and $0.1-5 \mathrm{mM} \mathrm{HCO}_{3}{ }^{-}$or for 7 days in the presence of $95 \mu \mathrm{M} \mathrm{U}(\mathrm{VI}), 1 \mathrm{mM} \mathrm{HCO}_{3}{ }^{-}$,

and $0-10 \mathrm{mM} \mathrm{Ca}^{2+}$ (3 replicate sets) at equilibrium $\mathrm{pH}$ of $\sim 6.5-7.0$. For all experiments, ionic strength was adjusted to $0.1 \mathrm{M}$ with $\mathrm{NaNO}_{3}$. After reaction, the supernatant was collected by centrifugation at $3000 \mathrm{rpm}$ for 10 minutes and analyzed as described below. The final $\mathrm{pH}$ was measured using a pH meter (Accumet XL20, Fisher Scientific).

After 2-day sorption experiments of $90 \mu \mathrm{M} \mathrm{U}(\mathrm{VI})$, the soil samples were rinsed twice with deionized water, and then subjected to sequential desorption by $10 \mathrm{~mL}$ of 1,10 , and $100 \mathrm{mM}$ $\mathrm{NaHCO}_{3}$. Each desorption step lasted 24 hrs. A set of soil samples exposed to $95 \mu \mathrm{M} \mathrm{U}(\mathrm{VI})$ in the presence of $\mathrm{Ca}^{2+}$ and $\mathrm{HCO}_{3}{ }^{-}$for 1 week were extracted with $10 \mathrm{mM} \mathrm{NaHCO}_{3}$ for 30 minutes to 1 week. Subsamples $(100 \mu \mathrm{L})$ were taken for $\mathrm{U}(\mathrm{VI})$ analysis after centrifugation at $3000 \mathrm{rpm}$ for 10 minutes. Dissolved U(VI) concentrations for sorption and desorption experiments were determined using a kinetic phosphorescence analyzer (KPA-11) (ChemChek Instruments, Richland, WA) (Brina and Miller, 1992). Analytical error was less than $\pm 5 \%$. Sorbed U(VI) was determined by the difference between the initial and final aqueous U(VI) concentrations.

\section{Results}

\subsection{Mineralogy of saprolite subsoils and nanoporous structure of goethite}


XRD analysis showed that the $<2 \mathrm{~mm}$ fraction of all three saprolite subsoils (low, medium and high Fe(III) soils: 7138, 11161, and $22582 \mathrm{mg} / \mathrm{kg} \mathrm{Fe}$ ) is composed mainly of quartz, illite and smectite, while a minor peak of calcite was identified in the low Fe(III) soil (Fig. 1). Nanogoethite was observed in all three soils by TEM (Fig. 2). The goethite was closely associated with illilte/smectite (I/S), and exhibited nanocrystalline and nanoporous structures, particularly in the medium and high Fe(III) soils (Fig. 2). Goethite in the high Fe(III) soil was dominated by aggregates of nano-crystals with an average size of $\sim 5 \mathrm{~nm}$. Very broad diffraction rings (insert in lower-right corner of Fig. 2A) indicate the goethite nano-crystals in the high Fe(III) soil are poorly crystalline. A high-resolution TEM image (Fig. 2B) displayed nanopore space between the goethite nano-crystals. The structural state of goethite in the high and medium Fe(III) soils is between ideal goethite and ferrihydrite (Fig. 2A-2C). The goethite may be formed through oriented aggregation of its precursor ferrihydrite nano-crystals, as suggested by Banfield et al (Banfield et al., 2000). Therefore the amount of Fe(III) oxides determined by the DCB extraction represents both goethite and ferrihydrite. Goethite nano-crystals are fewer in the low Fe(III) soil (Fig. 2D) than in the medium and high Fe(III) soils, which resulted in less nanopore surfaces in low Fe(III) soil. Quantitative X-ray energy-dispersive spectroscopy (EDS) analyses showed that all the goethite nano-crystals contained small amounts of $\mathrm{Al}$ (13-16 mole \% Al) (Fig. 2E).

For the low, medium, and high Fe(III) soil samples, BET specific surface area was 25, 29, and $38 \mathrm{~m}^{2} / \mathrm{g}$, respectively, while nanoporosity was $1.5,2.0$, and $1.9 \mu \mathrm{L} / \mathrm{g}$ for pore size $<2 \mathrm{~nm}$, and $16.3,18.4$, and $30.4 \mu \mathrm{L} / \mathrm{g}$ for pore size $<10 \mathrm{~nm}$, respectively (Table 1 , Fig. 3). BJH pore volume for larger pores with size between $10 \mathrm{~nm}$ and $120 \mathrm{~nm}$ are 19.1, 20.1, and $56.4 \mu \mathrm{L} / \mathrm{g}$ for low, medium and high Fe(III) soil samples, respectively. The particle size distribution by weight 
determined by sieving with a $0.063 \mathrm{~mm}$ sieve was similar for all 3 soil samples, showing $\sim 80 \%$ sand and $\sim 20 \%$ silt and clay.

\subsection{Dominant role of nano-goethite in $U(V I)$ sorption}

The low, medium, and high Fe(III) soils sorbed 3.4, 6.3, and $7.0 \mu \mathrm{mol} \mathrm{U}(\mathrm{VI}) / \mathrm{g}$, respectively, when $0.2 \mathrm{~g}$ of soil was exposed to $10 \mathrm{~mL}$ of $0.1 \mathrm{M} \mathrm{NaNO}_{3}$ solution containing $150 \mu \mathrm{M} \mathrm{U}(\mathrm{VI})$ and $1 \mathrm{mM} \mathrm{NaHCO} 3$ at $\mathrm{pH} 6.8$ for 1 week. TEM-EDS analysis revealed that most of the sorbed U(VI) was associated with nano-goethite clusters, displaying distinct $U$ peaks in their EDS spectra, whereas U peaks from clay minerals (e.g., illite, smectite) were low, and not distinctive from background peaks (Fig. 4). The U peak for nano-goethite clusters was relatively higher in the high and medium Fe(III) soils than the low Fe(III) soil, consistent with approximately 2-fold higher concentrations of sorbed U(VI) in the high and medium Fe(III) soils than the low Fe(III) soil. Although clays are much more abundant than goethite in FRC saprolite soils, TEM-EDS results indicate that the nano-goethite crystals play the dominant role in controlling U(VI) sorption. This is also consistent with a previous TEM-EDS study that identified iron oxyhydroxides as a distinct solid phase hosts for uranium in U(VI) contaminated FRC soils from Area 3 (Stubbs et al., 2006). Besides goethite and trace amount of Mn oxides (Table 1), no other secondary oxide minerals that are likely to affect $U(V I)$ sorption were identified from the saprolite subsoil by our TEM or XRD analyses.

\subsection{U(VI) sorption behavior in saprolite subsoils}

Sorption of $90-95 \mu \mathrm{M} \mathrm{U}(\mathrm{VI})$ to all three soils in $0.1 \mathrm{M} \mathrm{NaNO}_{3}$ solution was rapid, regardless

of the presence of $\mathrm{HCO}_{3}{ }^{-}(1 \mathrm{mM})$ or $\mathrm{Ca}^{2+}(0-10 \mathrm{mM})$. In the medium and high $\mathrm{Fe}(\mathrm{III})$ soils, the 
$\mathrm{U}(\mathrm{VI})$ sorption rapidly increased to $66-73 \%$ and $74-89 \%$, respectively in 20 minutes, and then slowly increased to $72-82 \%$ and $86-95 \%$, respectively in 48 hours (Fig. 5). In the low Fe(III) soil, the $\mathrm{U}(\mathrm{VI})$ sorption increased rapidly to $42-56 \%$ in 20 minutes, but remained relatively constant at $41-52 \%$ in 48 hours. After two days of sorption reaction, $\mathrm{pH}$ increased slightly from 6.3 to 6.5 in the medium and high $\mathrm{Fe}(\mathrm{III})$ soil suspensions, while $\mathrm{pH}$ increased from 6.3 to 7.0 in the low$\mathrm{Fe}(\mathrm{III})$ soil suspension likely due to dissolution of minor amount of calcite (Fig. 1). Given that $\mathrm{U}(\mathrm{VI})$ sorption to $\mathrm{Fe}(\mathrm{III})$ oxyhydroxides (e.g., ferrihydrite and goethite) in the presence of $\mathrm{HCO}_{3}{ }^{-}$ is the highest at circumneutral pH between 6 and 8 (Hsi and Langmuir, 1985; Waite et al., 1994; Wazne et al., 2003), the $\mathrm{pH}$ increase from 6.3 to 6.5 or 7.0 is likely to have an insignificant effect on U(VI) sorption to goethite in saprolite subsoils. Sorption of $50 \mu \mathrm{M} \mathrm{U}(\mathrm{VI})$ to the soils in the presence of $2.5 \mathrm{mM} \mathrm{Ca}^{2+}$ and $5 \mathrm{mM} \mathrm{HCO}_{3}{ }^{-}$at circumneutral equilibrium $\mathrm{pH}$ of $\sim 6.5-7.0$ for 2 weeks also showed initially rapid $\mathrm{U}(\mathrm{VI})$ sorption with 16,27 , and $50 \%$ sorption to low, medium, and high Fe(III) soils in 2 days, respectively. Then the U(VI) sorption to low, medium, and high Fe(III) soils increased slowly to 22,40 , and $66 \%$ in 1 week, and subsequently to 32,51 , and $73 \%$ in 2 weeks, respectively (Fig. 5).

The 2-day sorption of $90 \mu \mathrm{M} \mathrm{U}(\mathrm{VI})$ to the saprolite soils in $0.1 \mathrm{M} \mathrm{NaNO}_{3}$ solution decreased markedly with increasing $\mathrm{HCO}_{3}{ }^{-}$concentration from $0.1 \mathrm{mM}$ to $5 \mathrm{mM}$ because of increased formation of uranyl-carbonato species (Wazne et al., 2003; Davis et al., 2004): 47\% to 14\% for the low Fe(III) soil, $84 \%$ to $29 \%$ for the medium Fe(III) soil, and $99 \%$ to $36 \%$ for the high Fe(III) soil (Fig. 6A). PHREEQC modeling (Parkhurst and Appelo, 1999) predicted the speciation of $90 \mu \mathrm{M} \mathrm{U}(\mathrm{VI})$ at equilibrium $\mathrm{pH}$ of 6.5-7.0 using the databases from Bernhard et al (2001) and Guillaumont et al (2003), as well as the LLNL.dat database (a database file in PHREEQC) (Bernhard et al., 2001; Guillaumont et al., 2003). Uranyl-carbonato species (e.g., 
$\left.\mathrm{UO}_{2}\left(\mathrm{CO}_{3}\right)_{2}{ }^{2-}, \mathrm{UO}_{2}\left(\mathrm{CO}_{3}\right)_{3}{ }^{4-}\right)$ account for $0-1 \%, 24-26 \%$ and $95-98 \%$ of total $\mathrm{U}(\mathrm{VI})$ in the presence of $0.1,1$ and $5 \mathrm{mM} \mathrm{HCO}_{3}{ }^{-}$, respectively.

The extent of U(VI) sorption was higher with increasing soil Fe(III) oxide content, regardless of $\mathrm{HCO}_{3}{ }^{-}$concentration. Distribution coefficient $(\mathrm{Kd})$ for $\mathrm{U}(\mathrm{VI})$ in the presence of $0.1-5 \mathrm{mM}$ $\mathrm{HCO}_{3}{ }^{-}$increased from $2-9 \mathrm{~mL} / \mathrm{g}$ for the low Fe(III) soil to $4-52 \mathrm{~mL} / \mathrm{g}$ for the medium $\mathrm{Fe}(\mathrm{III})$ soil and $6-850 \mathrm{~mL} / \mathrm{g}$ for the high $\mathrm{Fe}(\mathrm{III})$ soil (Fig. $6 \mathrm{~B}$ ). The dominant role of soil Fe(III) oxides in $\mathrm{U}(\mathrm{VI})$ sorption has also been documented for materials from other DOE sites (the Savannah River and Hanford sites) (Barnett et al., 2002; Barnett et al., 2000).

The 1-week sorption of $95 \mu \mathrm{M} \mathrm{U}(\mathrm{VI})$ to the saprolite subsoils (3 replicate sets) in $0.1 \mathrm{M}$ $\mathrm{NaNO}_{3}$ solution with $1 \mathrm{mM} \mathrm{HCO}_{3}{ }^{-}$was lower only slightly in the presence of 5 or $10 \mathrm{mM} \mathrm{Ca}^{2+}$ than in the absence of $\mathrm{Ca}^{2+}$ (Fig. 6C). As $\mathrm{Ca}^{2+}$ concentration increased from $0 \mathrm{mM}$ to $5 \mathrm{mM}$ and $10 \mathrm{mM}$, the extent of $\mathrm{U}(\mathrm{VI})$ sorption decreased from $46 \%$ to $42 \%$ and $32 \%$ for the low $\mathrm{Fe}(\mathrm{III})$ soil, from $83 \%$ to $78 \%$ and $70 \%$ for the medium Fe(III) soil, and from $93 \%$ to $87 \%$ and $85 \%$ for high $\mathrm{Fe}(\mathrm{III})$ soil. This result is consistent with the minor effect of $\mathrm{Ca}$ on $\mathrm{U}(\mathrm{VI})$ sorption onto a saprolite soil collected from 1 to $1.5 \mathrm{~m}$ depth at the Melton Branch Watershed on the Oak Ridge Reservation (Gadelle et al., 2001). The distribution coefficient (Kd) increased with higher soil Fe(III) oxide content: from $5-9 \mathrm{~mL} / \mathrm{g}$ for the low Fe(III) soil to $23-51 \mathrm{~mL} / \mathrm{g}$ for the medium Fe(III) soil and 56-143 $\mathrm{mL} / \mathrm{g}$ for the high Fe(III) soil (Fig. 6D). Based on the PHREEQC modeling for the speciation of $95 \mu \mathrm{M} \mathrm{U}(\mathrm{VI})$ at equilibrium $\mathrm{pH}$ of $6.5-7.0$, uranyl-calciumcarbonato ternary species account for $0 \%, 36-60 \%$ and $63-83 \%$ of total $\mathrm{U}(\mathrm{VI})$ in the presence of 0, 5 and $10 \mathrm{mM} \mathrm{Ca}^{2+}$ with $1 \mathrm{mM} \mathrm{HCO}_{3}^{-}$, respectively. Uranyl-carbonato species compose 23$25 \%, 9-16 \%$, and $4-9 \%$ of total U(VI) in the presence of 0,5 and $10 \mathrm{mM} \mathrm{Ca}^{2+}$ with $1 \mathrm{mM} \mathrm{HCO}_{3}^{-}$ 
, respectively at $\mathrm{pH}$ of 6.5-7.0, while uranyl-hydroxyl-carbonato species (e.g., $\left.\left(\mathrm{UO}_{2}\right)_{2} \mathrm{CO}_{3}(\mathrm{OH})_{3}{ }^{-}\right)$ are $66-68 \%, 26-42 \%$ and $10-23 \%$ of total $\mathrm{U}(\mathrm{VI})$, respectively.

\subsection{U(VI) desorption behavior in saprolite subsoils}

Estimation of the labile fraction of $\mathrm{U}(\mathrm{VI})$ that participates in sorption-desorption processes, as well as any non-labile fraction (Phillips et al., 1995) that is resistant to desorption, is critical for predicting the mobility and transport of $\mathrm{U}(\mathrm{VI})$ in subsurface environments. Sodium bicarbonate $\left(\mathrm{NaHCO}_{3}\right)$ extraction at varying concentration has been used to selectively remove U(VI) from natural soils and sediments (Elias et al., 2003; Gadelle et al., 2001; Kohler et al., 2004; Mason et al., 1997; Zhou and Gu, 2005). Soils exposed to $90 \mu \mathrm{M} \mathrm{U}(\mathrm{VI})$ for two days in the presence of varying $\mathrm{HCO}_{3}{ }^{-}$concentration $(0.1,1$, or $5 \mathrm{mM}$ ) were extracted sequentially (24 hours per extraction) at a range of $\mathrm{NaHCO}_{3}$ concentrations $(1,10$, and $100 \mathrm{mM})$. The combined proportion of $\mathrm{U}(\mathrm{VI})$ released from the saprolite soils by $1 \mathrm{mM}$ and $10 \mathrm{mM} \mathrm{NaHCO}_{3}$ [relatively more labile U(VI) fraction)] decreased with increasing amount of Fe(III) oxides: 54-67\% for the low Fe(III) soil, $34-52 \%$ for the medium Fe(III) soil, $28-31 \%$ for the high Fe(III) soil (Fig. 7). Correspondingly, the less labile $\mathrm{U}(\mathrm{VI})$ fraction [U(VI) released by $100 \mathrm{mM} \mathrm{NaHCO}_{3}+$ undesorbed $\mathrm{U}(\mathrm{VI})]$ was greater with increasing amount of Fe(III) oxides: $33-46 \%$ for the low Fe(III) soil, $48-66 \%$ for the medium Fe(III) soil, and $69-72 \%$ for the high Fe(III) soil. The sequential desorption of $\mathrm{U}(\mathrm{VI})$ sorbed to the saprolite subsoils indicates that $\mathrm{U}(\mathrm{VI})$ sorption tends to be more irreversible in the presence of higher amount of nanoporous goethite.

After sorption experiments with $95 \mu \mathrm{M} \mathrm{U}(\mathrm{VI})$ in the presence of $\mathrm{Ca}^{2+}$ and $\mathrm{HCO}_{3}{ }^{-}$(Fig. 6), time course experiments of $\mathrm{U}(\mathrm{VI})$ desorption from a set of saprolite soils by $10 \mathrm{mM} \mathrm{NaHCO}$ over 1 week generally exhibited two-step desorption behavior (Fig. 8): an initial fast desorption 
step during the first $24 \mathrm{hrs,}$, followed by slow desorption step lasting several days. Multiple steps of $\mathrm{U}(\mathrm{VI})$ desorption over days or weeks have been also reported from $20 \mathrm{mM}$ carbonate extraction of natural sediments of former $\mathrm{U}$ mill tailings sites at Naturita and Rifle, CO (Hyun et al., 2009; Kohler et al., 2004). During the first 24-hour desorption period, sorbed U(VI) concentration rapidly decreased from $0.29-0.41 \mu \mathrm{M} / \mathrm{g}$ to $0.18-0.30 \mu \mathrm{M} / \mathrm{g}$ for the low $\mathrm{Fe}(\mathrm{III})$ soil, from $0.64-0.74 \mu \mathrm{M} / \mathrm{g}$ to $0.21-0.25 \mu \mathrm{M} / \mathrm{g}$ for the medium Fe(III) soil, and from $0.75-0.83 \mu \mathrm{M} / \mathrm{g}$ to 0.42-0.58 $\mu \mathrm{M} / \mathrm{g}$ for the high Fe(III) soil (Fig. 8). Between 24-hour desorption and 7-day desorption, sorbed $\mathrm{U}(\mathrm{VI})$ concentration continued to decrease to $0.04-0.19 \mu \mathrm{M} / \mathrm{g}$ for the low $\mathrm{Fe}(\mathrm{III})$ soil, to $0.09-0.30 \mu \mathrm{M} / \mathrm{g}$ for the medium $\mathrm{Fe}(\mathrm{III})$ soil, and to $0.29-0.46 \mu \mathrm{M} / \mathrm{g}$ for high Fe(III) soil (Fig. 8). In general, the 1-week U(VI) desorption\% was lower for soil with higher amount of Fe(III) oxides: $61-86 \%$ for the low Fe(III) soil, $50-84 \%$ for the medium Fe(III) soil, 44-59\% for the high Fe(III) soil.

\section{Discussion}

The results show that the ORFRC saprolite soils contain nano-goethite with nanoporous structure, which provides the reactive surfaces for $\mathrm{U}(\mathrm{VI})$ sorption. $\mathrm{U}(\mathrm{VI})$ sorption to the saprolite soils is mainly attributed to poorly crystalline nanoporous goethite, which was probably transformed from ferrihydrite, not to isolated individual well-crystalline goethite. The U(VI) sorption to the ORFRC saprolite soils at circumneutral $\mathrm{pH}$ increased with higher amount of nano-goethite in the presence of $\mathrm{HCO}_{3}{ }^{-}$and $\mathrm{Ca}^{2+}$. The sorption of $95 \mu \mathrm{M} \mathrm{U}(\mathrm{VI})$ increased rapidly, reaching near equilibrium in less than 1 hour, but a slower sorption process continued in the medium and high Fe(III) soils (Fox et al., 2006; Waite et al., 1994). The sorption of $50 \mu \mathrm{M}$ U(VI) sorption for 2 weeks also showed a similar kinetic behavior: a rapid initial sorption 
followed by slower sorption. The time-dependence of $\mathrm{U}(\mathrm{VI})$ sorption is attributed to rapid sorption onto external surfaces of goethite, followed by intraparticle diffusion and sorption onto interior surface sites of the nanoporous goethite (Axe and Anderson, 1997; Trivedi and Axe, 2000; van Beinum et al., 2005).

The $\mathrm{U}(\mathrm{VI})$ desorption from the saprolite soils by $10 \mathrm{mM} \mathrm{NaHCO}_{3}$ over 1 week displayed two-step desorption behavior (Fig. 8). The two-step U(VI) desorption behavior suggests that the initial fast desorption of $\mathrm{U}(\mathrm{VI})$ from the soils is attributed to release of $\mathrm{U}(\mathrm{VI})$ bound to external surfaces of goethite, while the subsequent slower desorption step was associated with internal nanoporous surfaces of goethite (Wang et al., 2003). The less extensive U(VI) desorption by 1 or $10 \mathrm{mM} \mathrm{NaHCO}_{3}$ from the medium and high Fe(III) soils compared to the low Fe(III) soil (Fig. 7) is also attributable to the higher abundance of nanoporous goethite in the medium and high Fe(III) soils than the low $\mathrm{Fe}(\mathrm{III})$ soil (Fig. 2). U(VI) release from the medium and high $\mathrm{Fe}(\mathrm{III})$ soils was slower and more irreversible than $\mathrm{U}(\mathrm{VI})$ desorption from the low Fe(III) soil perhaps because of slower diffusion of ions in and out of nanopores or kinetically-hindered release of $\mathrm{U}(\mathrm{VI})$ due to strong $\mathrm{U}(\mathrm{VI})$ binding to internal nanoporous surfaces. Ion diffusivity is significantly reduced in nanopores compared to bulk water (Kerisit and Liu, 2009; Nagumo et al., 2008), posing mass transfer limitation on rates of U(VI) desorption. Due to slow diffusion of $\mathrm{HCO}_{3}{ }^{-}$into the nanopores of goethite and slower diffusion of $\mathrm{U}(\mathrm{VI})$ out of the nanopores of goethite, U(VI) desorption rate can decrease significantly. In addition, the presence of nanoporous domains may increase the intrinsic binding strength and decrease the desorbability of $\mathrm{U}(\mathrm{VI})$ through solvation energy effects. The solvation energy of charged ions is reduced in nanopores because of the lower dielectric constant of solvent water in nanopores than in bulk solution, which reduces the affinity for metal hydration in aqueous solution, thus increasing the 
tendency for inner sphere complexation and mineral precipitation (Senapati and Chandra, 2001; Wang, 2014; Wang et al., 2003). It has been also reported that the surface charge density on nanoparticles is significantly higher than that on non-nanoparticles under same chemical conditions (Abbas et al., 2008; Barisik et al., 2014; Wang, 2014; Wang et al., 2003; Wang et al., 2002).

A limited, partial desorption of $\mathrm{U}(\mathrm{VI})$ by $10-100 \mathrm{mM} \mathrm{HCO}_{3}^{-}$from $\mathrm{U}(\mathrm{VI})$ contaminated sediment/soil has been previously reported (Curtis et al., 2004; Gadelle et al., 2001; Kohler et al., 2004; Phillips et al., 1995). The mass of labile U(VI) in U-contaminated aquifer sediments from a former $\mathrm{U}$ mill tailings site at Naturita, $\mathrm{CO}$, was estimated by the sodium bicarbonate/carbonate extraction of $20 \mathrm{meq} / \mathrm{L}$ alkalinity, which accounted for approximately $10-40 \%$ of total sediment U (Curtis et al., 2004; Kohler et al., 2004). In contrast, nearly all solid phase U(VI) was successfully removed from contaminated soils from the Fernald Environmental Management Project (FEMP) site near Fernald, OH and from the field research center (FRC) in Oak Ridge, TN using sodium bicarbonate of 0.5-1 M (Mason et al., 1997; Zhou and Gu, 2005). The extraction effectiveness of $\sim 0.1 \mathrm{M}$ sodium bicarbonate varied from 20 to $94 \%$ of total sorbed U(VI), depending on the types of soil (Gadelle et al., 2001; Phillips et al., 1995). In this study, the sequential extraction of U(VI) sorbed to the ORFRC saprolite subsoils by 1 to 10 and 100 $\mathrm{mM} \mathrm{HCO}_{3}{ }^{-}$resulted in only partial desorption of $\mathrm{U}(\mathrm{VI}): 67-80 \%$ desorption from the low $\mathrm{Fe}(\mathrm{III})$ soil, $54-68 \%$ desorption from the medium Fe(III) soil, $65-70 \%$ desorption from the high $\mathrm{Fe}(\mathrm{III})$ soil. It is likely that the bioavailability of $\mathrm{U}(\mathrm{VI})$ sorbed on nanoporous goethite is significantly reduced because nanoporous domains of Fe(III) oxides are highly effective at stabilizing U(VI) against desorption (Chevallier et al., 2010; Zachara et al., 2016). Microorganisms with a typical size of micrometers cannot directly access $\mathrm{U}(\mathrm{VI})$ inside nanopores, which also effectively 
reduces the bioavailability of U(VI) (Wang, 2014). Although many details remain unclear (e.g., the relative importance of mass transfer vs. intrinsic binding strength effects related to nanopores; the correlation between nanopore abundance and the presence of various $\mathrm{Fe}(\mathrm{III})$ oxide and other mineral phases), our experimental data for natural subsurface soils from ORFRC suggest that nanopores within nano-crystalline $\mathrm{Fe}(\mathrm{III})$ oxides may exert a significant role in regulating the sorption-desorption behavior, and hence the mobility and transport of $U(V I)$ in subsurface environments where such phases are abundant.

\section{Conclusions}

The U(VI) sorption-desorption behavior in ORFRC saprolite subsurface soils was investigated. The saprolite subsoils were essentially homogeneous in mineral composition and particle size distribution, but were characterized by a range of DCB extractable Fe(III) oxide content and different pore size distributions. Key conclusions from this study include:

1. TEM imaging revealed that nanopores were formed between aggregated nano-goethite crystals, particularly in the medium and high Fe(III) saprolite subsoils.

2. TEM-EDS analysis exhibited that U(VI) sorption occurred predominantly on nano-goethite crystals rather than clay minerals, and higher $\mathrm{U}$ peaks were detected on nanoporous goethite clusters in the medium or high Fe(III) soils than on crystalline goethite clusters in the low Fe(III) soil.

3. A higher extent of $\mathrm{U}(\mathrm{VI})$ sorption at variable $\mathrm{Ca}^{2+}$ and $\mathrm{HCO}_{3}{ }^{-}$concentrations and a lower extent of $\mathrm{U}(\mathrm{VI})$ desorption by $1-100 \mathrm{mM} \mathrm{NaHCO}_{3}$ took place in the soil with higher quantity of nanoporous goethite. 
4. The initial fast desorption of U(VI) from the ORFRC saprolite subsoils (24-hour time scale) seems to result from release of $\mathrm{U}(\mathrm{VI})$ from external surfaces of goethite, while the subsequent slower desorption phase was attributed to slower diffusion of $\mathrm{HCO}_{3}{ }^{-}$and $\mathrm{U}(\mathrm{VI})$ in and out of nanopores of goethite or kinetically-hindered release of U(VI) from internal nanoporous surfaces of goethite due to strong U(VI) binding to nanoporous surfaces.

Overall, the results of this study shed light on the role of nano-goethite in enhancing the sorption and retention of $\mathrm{U}(\mathrm{VI})$ in subsurface ORFRC soil. This phenomenon has thus far been poorly recognized because numerous previous laboratory studies of U(VI) sorption by natural soil or sediment have not focused on nanoporous or nanocrystalline minerals. Our findings imply that understanding of sorption-desorption behavior of $\mathrm{U}(\mathrm{VI})$ on nanoporous mineral surfaces will be critical to better predict the mobility and transport of $\mathrm{U}(\mathrm{VI})$ in subsurface environment where nanoporous minerals are ubiquitous and abundant.

\section{Acknowledgements}

This work is supported by U. S. Department of Energy (DE-SC0002150). We are grateful to Yubing Sun who helped the measurement of specific surface area and pore size of ORFRC soils. 


\section{References}

Abbas, Z., Labbez, C., Nordholm, S., Ahlberg, E., 2008. Size-dependent surface charging of nanoparticles. Journal of Physical Chemistry C 112, 5715-5723.

Axe, L., Anderson, P.R., 1997. Experimental and theoretical diffusivities of $\mathrm{Cd}$ and $\mathrm{Sr}$ in hydrous ferric oxide. Journal of Colloid and Interface Science 185, 436-448.

Banfield, J.F., Welch, S.A., Zhang, H.Z., Ebert, T.T., Penn, R.L., 2000. Aggregation-based crystal growth and microstructure development in natural iron oxyhydroxide biomineralization products. Science 289, 751-754.

Barisik, M., Atalay, S., Beskok, A., Qian, S., 2014. Size Dependent Surface Charge Properties of Silica Nanoparticles. Journal of Physical Chemistry C 118, 1836-1842.

Barnett, M.O., Jardine, P.M., Brooks, S.C., 2002. U(VI) adsorption to heterogeneous subsurface media: Application of a surface complexation model. Environmental Science \& Technology 36, 937-942.

Barnett, M.O., Jardine, P.M., Brooks, S.C., Selim, H.M., 2000. Adsorption and transport of uranium(VI) in subsurface media. Soil Science Society of America Journal 64, 908-917.

Bernhard, G., Geipel, G., Reich, T., Brendler, V., Amayri, S., Nitsche, H., 2001. Uranyl(VI) carbonate complex formation: Validation of the Ca2UO2(CO3)(3)(aq.) species. Radiochimica Acta 89, 511-518.

Brina, R., Miller, A.G., 1992. Direct detection of trace levels of uranium by laser-induced kinetic phosphorimetry. Analytical Chemistry 64, 1413-1418.

Chevallier, T., Woignier, T., Toucet, J., Blanchart, E., 2010. Organic carbon stabilization in the fractal pore structure of Andosols. Geoderma 159, 182-188.

Curtis, G.P., Fox, P., Kohler, M., Davis, J.A., 2004. Comparison of in situ uranium K-D values with a laboratory determined surface complexation model. Applied Geochemistry 19, 16431653.

Davis, J.A., Meece, D.E., Kohler, M., Curtis, G.P., 2004. Approaches to surface complexation modeling of uranium(VI) adsorption on aquifer sediments. Geochimica Et Cosmochimica Acta 68, 3621-3641.

Dong, W.M., Ball, W.P., Liu, C.X., Wang, Z.M., Stone, A.T., Bai, J., Zachara, J.M., 2005. Influence of calcite and dissolved calcium on uranium(VI) sorption to a Hanford subsurface sediment. Environmental Science \& Technology 39, 7949-7955.

Elias, D.A., Senko, J.M., Krumholz, L.R., 2003. A procedure for quantitation of total oxidized uranium for bioremediation studies. J. Microbiol. Methods 53, 343-353.

Fox, P.M., Davis, J.A., Zachara, J.M., 2006. The effect of calcium on aqueous uranium(VI) speciation and adsorption to ferrihydrite and quartz. Geochimica Et Cosmochimica Acta 70, 1379-1387.

Gadelle, F., Wan, J.M., Tokunaga, T.K., 2001. Removal of Uranium(VI) from contaminated sediments by surfactants. Journal of Environmental Quality 30, 470-478.

Gilbert, B., Ono, R.K., Ching, K.A., Kim, C.S., 2009. The effects of nanoparticle aggregation processes on aggregate structure and metal uptake. J Colloid Interface Sci 339, 285-295.

Guillaumont, R., Fanghanel, T., Neck, V., Fuger, J., Palmer, D.A., Grenthe, I., Rand, M.H., 2003. Update on the Chemical Thermodynamics of Uranium, Neptunium, Plutonium, Americium, and Technetium. Elsevier, Amsterdam. 
Hochella, M.F., 2008. Nanogeoscience: From Origins to Cutting-Edge Applications. Elements 4, 373-379.

Hsi, C.K.D., Langmuir, D., 1985. Adsorption of uranyl onto ferric oxyhydroxides - application of the surface complexation site-binding model Geochimica Et Cosmochimica Acta 49, 1931-1941.

Hyun, S.P., Fox, P.M., Davis, J.A., Campbell, K.M., Hayes, K.F., Long, P.E., 2009. Surface Complexation Modeling of U(VI) Adsorption by Aquifer Sediments from a Former Mill Tailings Site at Rifle, Colorado. Environmental Science \& Technology 43, 9368-9373.

Jackson, M.L., Lim, C. H., Zelazny, L.W., 1986. Oxides, hydroxides, and aluminosilicates, in: Klute, A. (Ed.), Methods of Soil Analysis. Part 1., 2nd ed. ed. ASA and SSSA, Madison, WI.

Jeon, B.H., Kelly, S.D., Kemner, K.M., Barnett, M.O., Burgos, W.D., Dempsey, B.A., Roden, E.E., 2004. Microbial reduction of U(VI) at the solid-water interface. Environmental Science \& Technology 38, 5649-5655.

Jung, H.B., Boyanov, M.I., Konishi, H., Sun, Y.B., Mishra, B., Kemner, K.M., Roden, E.E., Xu, H.F., 2012. Redox Behavior of Uranium at the Nanoporous Aluminum Oxide-Water Interface: Implications for Uranium Remediation. Environmental Science \& Technology 46, 7301-7309.

Kerisit, S., Liu, C., 2009. Molecular Simulations of Water and Ion Diffusion in Nanosized Mineral Fractures. Environ. Sci. Technol. 43, 777-782.

Kohler, M., Curtis, G.P., Meece, D.E., Davis, J.A., 2004. Methods for estimating adsorbed uranium(VI) and distribution coefficients of contaminated sediments. Environmental Science \& Technology 38, 240-247.

Langmuir, D., 1997. Aqueous Environmental Geochemistry. Prentice Hall, New York.

Lottermoser, B.G., Ashley, P.M., 2005. Tailings dam seepage at the rehabilitated Mary Kathleen uranium mine, Australia. Journal of Geochemical Exploration 85, 119-137.

Mason, C.F.V., Turney, W., Thomson, B.M., Lu, N., Longmire, P.A., ChisholmBrause, C.J., 1997. Carbonate leaching of uranium from contaminated soils. Environmental Science \& Technology 31, 2707-2711.

McKinley, J.P., Zachara, J.M., Wan, J., McCready, D.E., Heald, S.M., 2007. Geochemical controls on contaminant uranium in vadose Hanford formation sediments at the 200 area and 300 area, Hanford Site, Washington. Vadose Zone Journal 6, 1004-1017.

Moon, J.W., Roh, Y., Phelps, T.J., Phillips, D.H., Watson, D.B., Kim, Y.J., Brooks, S.C., 2006. Physicochemical and mineralogical characterization of soil-saprolite cores from a field research site, Tennessee. Journal of Environmental Quality 35, 1731-1741.

Nagumo, R., Takaba, H., Nakao, S.-i., 2008. Accelerated computation of extremely 'slow' molecular diffusivity in nanopores. Chem. Phys. Lett. 458, 281-284.

Neiva, A.M.R., Carvalho, P.C.S., Antunes, I.M.H.R., Silva, M.M.V.G., Santos, A.C.T., Cabral Pinto, M.M.S., Cunha, P.P., 2014. Contaminated water, stream sediments and soils close to the abandoned Pinhal do Souto uranium mine, central Portugal. Journal of Geochemical Exploration 136, 102-117.

Parkhurst, D.L., Appelo, C.A.J., 1999. User's guide to PHREEQC (Version 2) - a computer program for speciation, batch-reaction, one-dimensional transport, and inverse geochemical calculations, Water-Resources Investigations Report 99-4259. U.S. Geological Survey, Denver, Colorado. 
Phillips, E.J.P., Landa, E.R., Lovley, D.R., 1995. Remediation of uranium contaminated soils with bicarbonate extraction and microbial $\mathrm{U}(\mathrm{VI})$ reduction Journal of Industrial Microbiology 14, 203-207.

Pignatello, J.J., Xing, B.S., 1996. Mechanisms of slow sorption of organic chemicals to natural particles. Environmental Science \& Technology 30, 1-11.

Senapati, S., Chandra, A., 2001. Dielectric constant of water confined in a nanocavity. Journal of Physical Chemistry B 105, 5106-5109.

Stubbs, J.E., Elbert, D.C., Veblen, D.R., Zhu, C., 2006. Electron microbeam investigation of uranium-contaminated soils from Oak Ridge, TN, USA. Environmental Science \& Technology 40, 2108-2113.

Sylwester, E.R., Hudson, E.A., Allen, P.G., 2000. The structure of uranium (VI) sorption complexes on silica, alumina, and montmorillonite. Geochimica Et Cosmochimica Acta 64, 2431-2438.

Trivedi, P., Axe, L., 2000. Modeling Cd and Zn sorption to hydrous metal oxides. Environmental Science \& Technology 34, 2215-2223.

van Beinum, W., Hofmann, A., Meeussen, J.C.L., Kretzschmar, R., 2005. Sorption kinetics of strontium in porous hydrous ferric oxide aggregates I. The Donnan diffusion model. Journal of Colloid and Interface Science 283, 18-28.

van der Zee, C., Roberts, D.R., Rancourt, D.G., Slomp, C.P., 2003. Nanogoethite is the dominant reactive oxyhydroxide phase in lake and marine sediments. Geology 31, 993-996.

Waite, T.D., Davis, J.A., Payne, T.E., Waychunas, G.A., Xu, N., 1994. Uranium(VI) adsorption to ferrihydrite - application of a surface complexation model Geochimica Et Cosmochimica Acta 58, 5465-5478.

Wang, Y., 2014. Nanogeochemistry: Nanostructures, emergent properties and their control on geochemical reactions and mass transfers. Chemical Geology 378, 1-23.

Wang, Y.F., Bryan, C., Xu, H.F., Gao, H.Z., 2003. Nanogeochemistry: Geochemical reactions and mass transfers in nanopores. Geology 31, 387-390.

Wang, Y.F., Bryan, C., Xu, H.F., Pohl, P., Yang, Y., Brinker, C.J., 2002. Interface chemistry of nanostructured materials: Ion adsorption on mesoporous alumina. Journal of Colloid and Interface Science 254, 23-30.

Wazne, M., Korfiatis, G.P., Meng, X.G., 2003. Carbonate effects on hexavalent uranium adsorption by iron oxyhydroxide. Environmental Science \& Technology 37, 3619-3624.

Zachara, J., Brantley, S., Chorover, J., Ewing, R., Kerisit, S., Liu, C., Perfect, E., Rother, G., Stack, A.G., 2016. Internal Domains of Natural Porous Media Revealed: Critical Locations for Transport, Storage, and Chemical Reaction. Environmental Science \& Technology 50, 2811-2829.

Zhou, P., Gu, B.H., 2005. Extraction of oxidized and reduced forms of uranium from contaminated soils: Effects of carbonate concentration and $\mathrm{pH}$. Environmental Science \& Technology 39, 4435-4440. 
Table 1. Summary of chemical, physical, and mineralogical characteristics of ORFRC saprolite subsoils. Prior to sorption-desorption experiments, background $U$ concentration in saprolite soils was determined by $10 \% \mathrm{HNO}_{3}$ extraction for 2 days. Fe(III) content was determined by DCB extraction. BET specific surface area and nanoporosity were analyzed by a surface area and pore size analyzer; Minerals were identified using XRD and TEM (Qz, Ill, Sm, and Cal represent quartz, illite, smectite, and calcite, respectively).

\begin{tabular}{|c|c|c|c|c|c|c|c|}
\hline \multirow[t]{2}{*}{ Sample ID } & \multirow{2}{*}{$\begin{array}{l}\text { U conc. } \\
\mu \mathrm{M} / \mathrm{g}\end{array}$} & \multirow{2}{*}{$\begin{array}{c}\mathrm{Fe}(\mathrm{III}) \text { conc. } \\
\mathrm{mg} / \mathrm{kg}\end{array}$} & \multirow{2}{*}{$\begin{array}{c}\text { Specific } \\
\text { surface area } \\
\mathrm{m}^{2} / \mathrm{g}\end{array}$} & \multicolumn{2}{|c|}{ Nanoporosity $(\mu \mathrm{L} / \mathrm{g})$} & \multicolumn{2}{|r|}{ Mineralogy } \\
\hline & & & & $<2 \mathrm{~nm}$ & $<10 \mathrm{~nm}$ & XRD & TEM \\
\hline Low Fe(III) & 0.0068 & 7138 & 25 & 1.5 & 16.3 & Qz, III, Sm, Cal & Goethite, Mn oxide (minor) \\
\hline Medium Fe(III) & 0.0015 & 11161 & 29 & 2.0 & 18.4 & Qz, III, Sm & Goethite \\
\hline High Fe(III) & 0.0016 & 22582 & 38 & 1.9 & 30.4 & Qz, III, Sm & Goethite \\
\hline
\end{tabular}




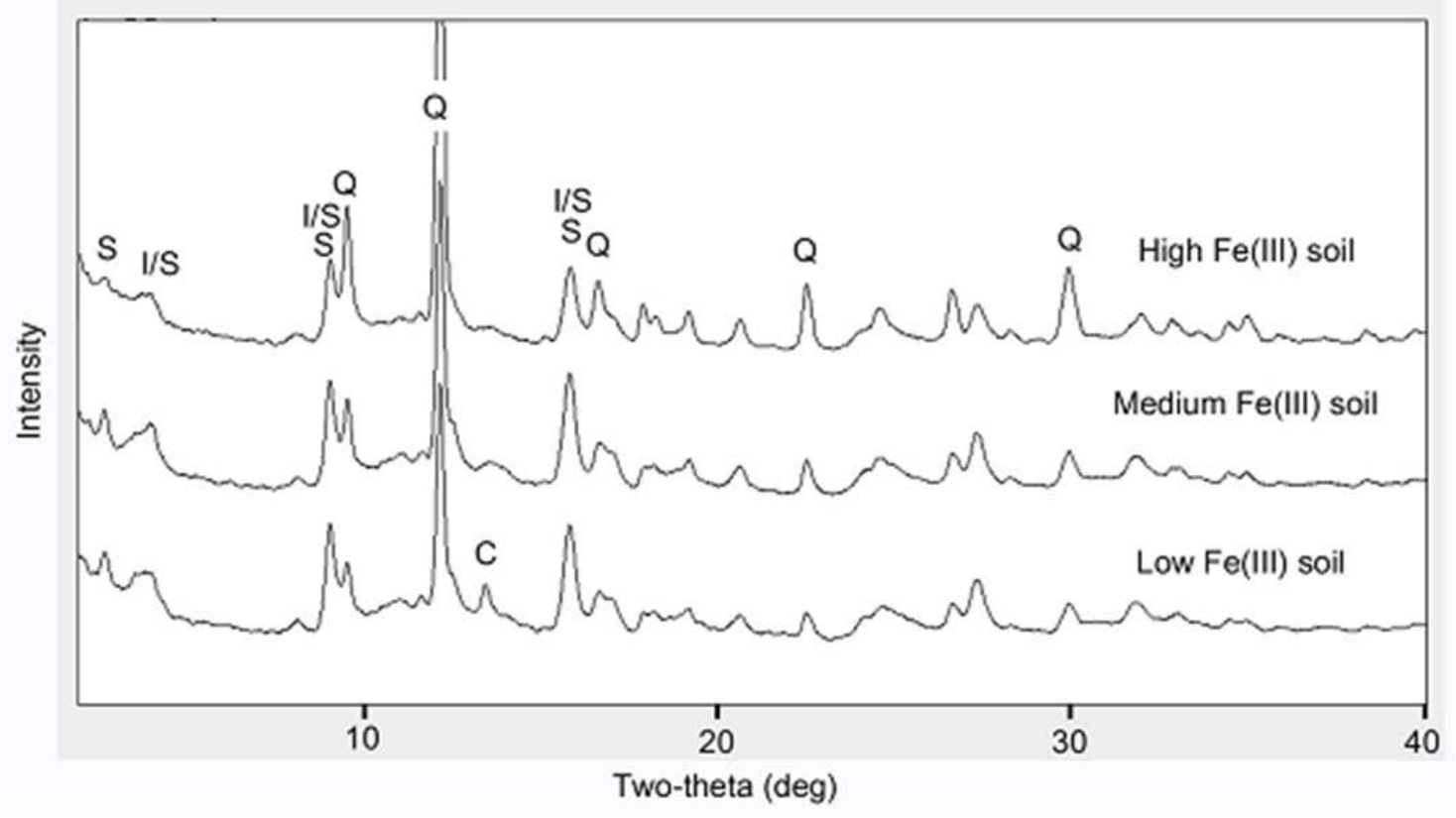

Fig. 1. X-ray diffraction patterns for ORFRC saprolite subsoils with low (GP-4-5-00), medium (GP-4-4-25), and high (GP-3-5-00) Fe(III) oxide content. Mineralogy in all samples is dominated by quartz (Q), illite (I), and smectite (S). The low Fe(III) subsoil shows a distinct 104 diffraction peak for calcite (C). 

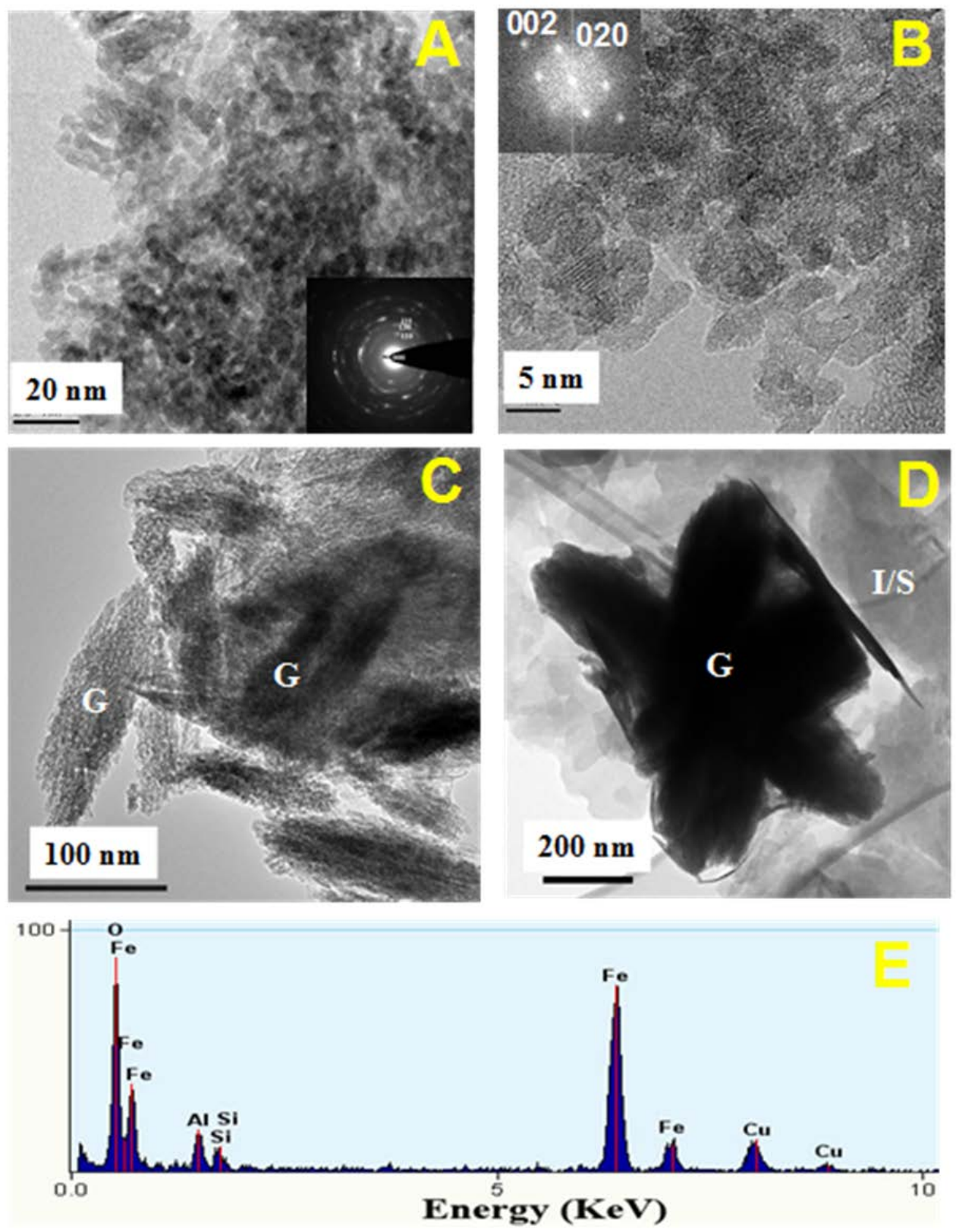

Fig. 2. TEM images showing nano-sized goethite in the high Fe(III) saprolite subsoil (A, B), as well as twined goethite ( $\mathrm{V}$-shape) consisting of oriented aggregation of goethite nano-crystals in the medium Fe(III) saprolite soil (C) and the low Fe(III) saprolite soil (D). I/S and G in TEM images indicate illite/smectite clay and goethite, respectively. X-ray EDS spectrum (E) shows small amount of $\mathrm{Al}$ in the goethite. $\mathrm{Cu}$ peak is from $\mathrm{Cu}$ grid holding the specimen. Si peak is from florescence peak of Li-drifted Si detector. 

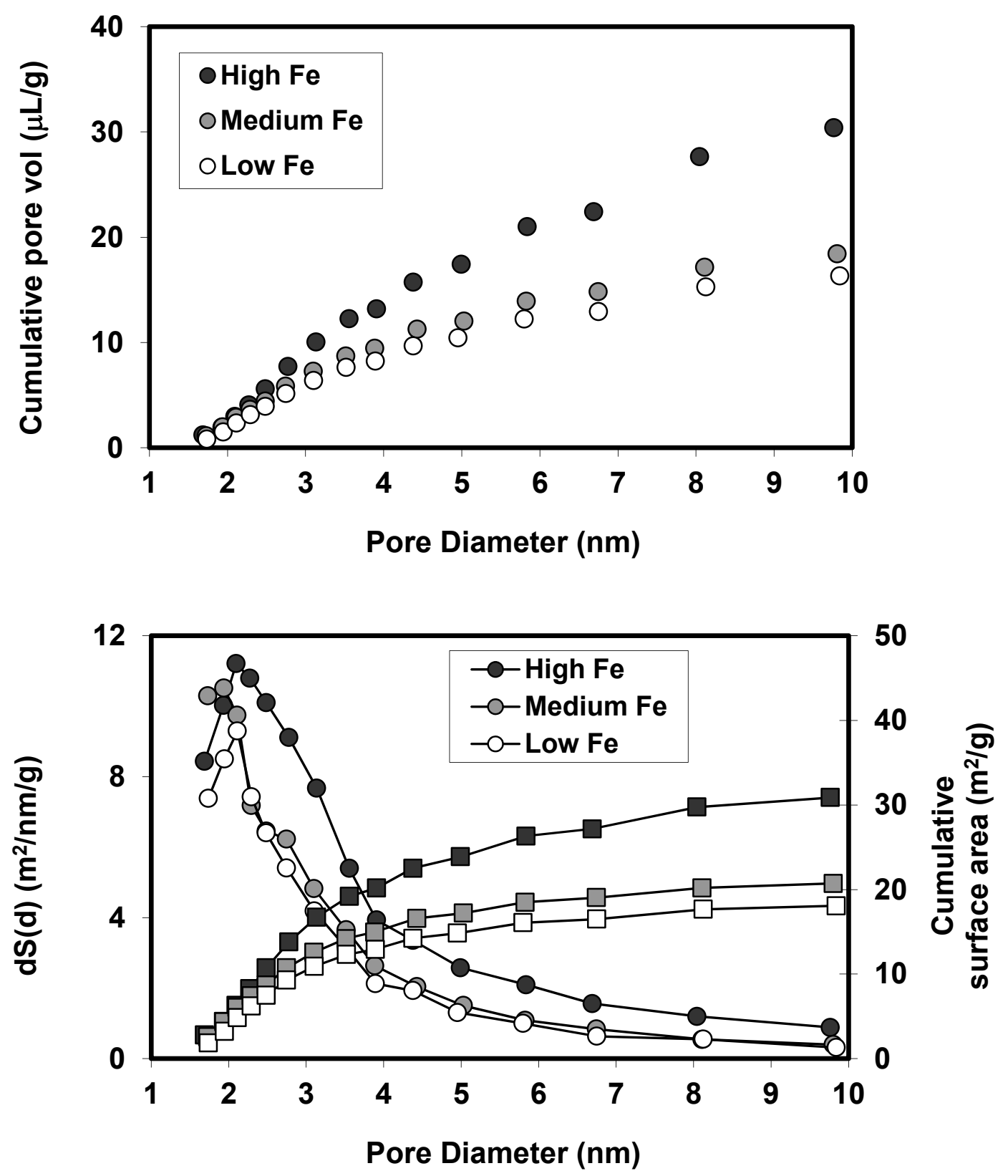

Fig. 3. Top: BJH cumulative pore volume in the low to high Fe(III) soils as a function of pore size. Bottom: BJH cumulative surface area (squares) as a function of pore size and BJH surface area distribution (circles) for the low to high Fe(III) soils. 

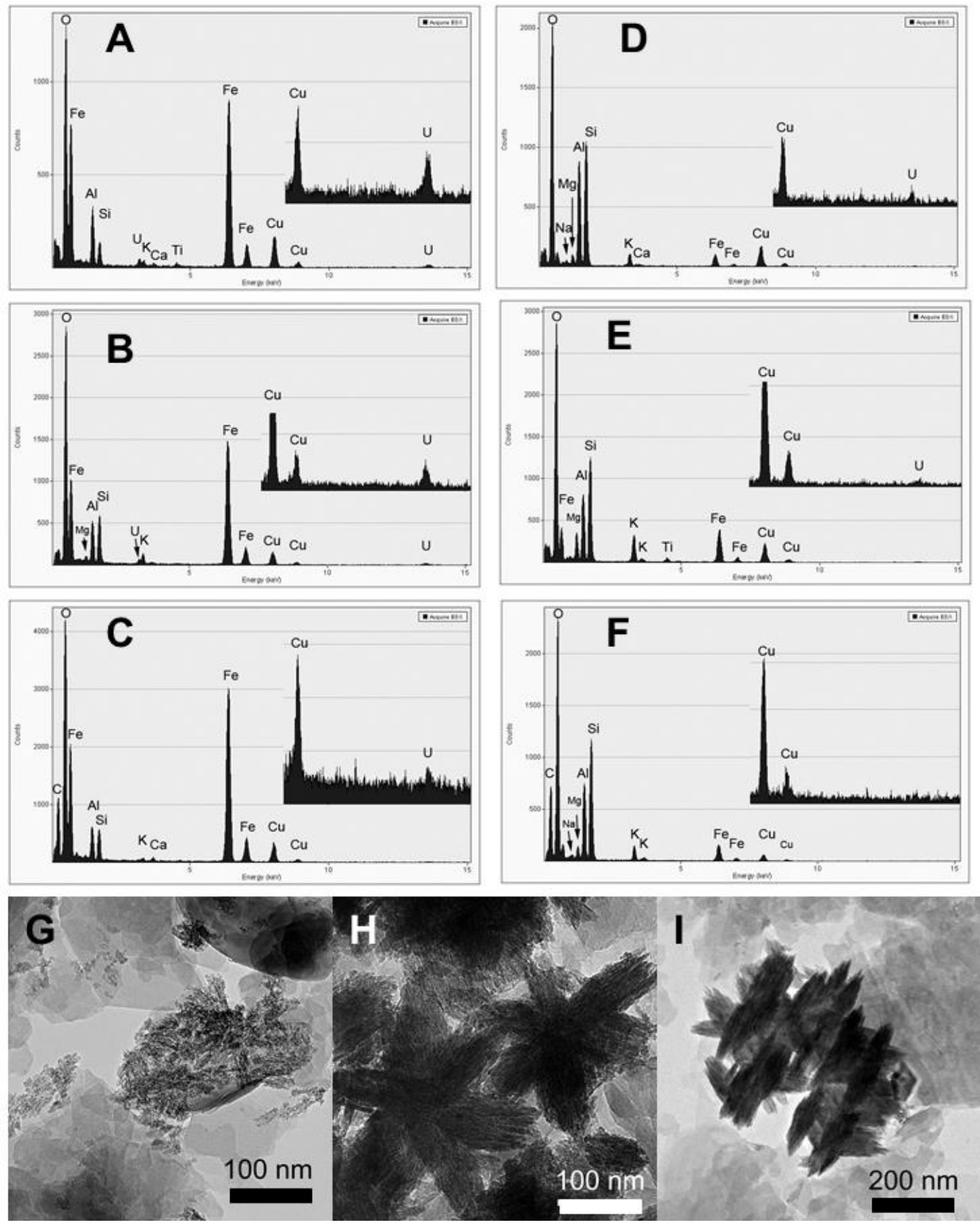

Fig. 4. TEM-EDS showing U(VI) concentrations sorbed on goethite nanoparticles (A: the high Fe(III) soil, B: the medium Fe(III) soil, C: the low Fe(III) soil) and clays (D: the high Fe(III) soil, E: the medium Fe(III) soil, F: the low Fe(III) soil). TEM images of nano-goethite clusters in the high $(\mathrm{G})$, medium $(\mathrm{H})$, and low (I) Fe(III) soils. Soil samples $(0.2 \mathrm{~g})$ were reacted with $0.1 \mathrm{M}$ $\mathrm{NaNO}_{3}$ solution containing $150 \mu \mathrm{M} \mathrm{U}(\mathrm{VI})$ and $1 \mathrm{mM} \mathrm{NaHCO}$ at $\mathrm{pH} 6.8$ for 1 week. 

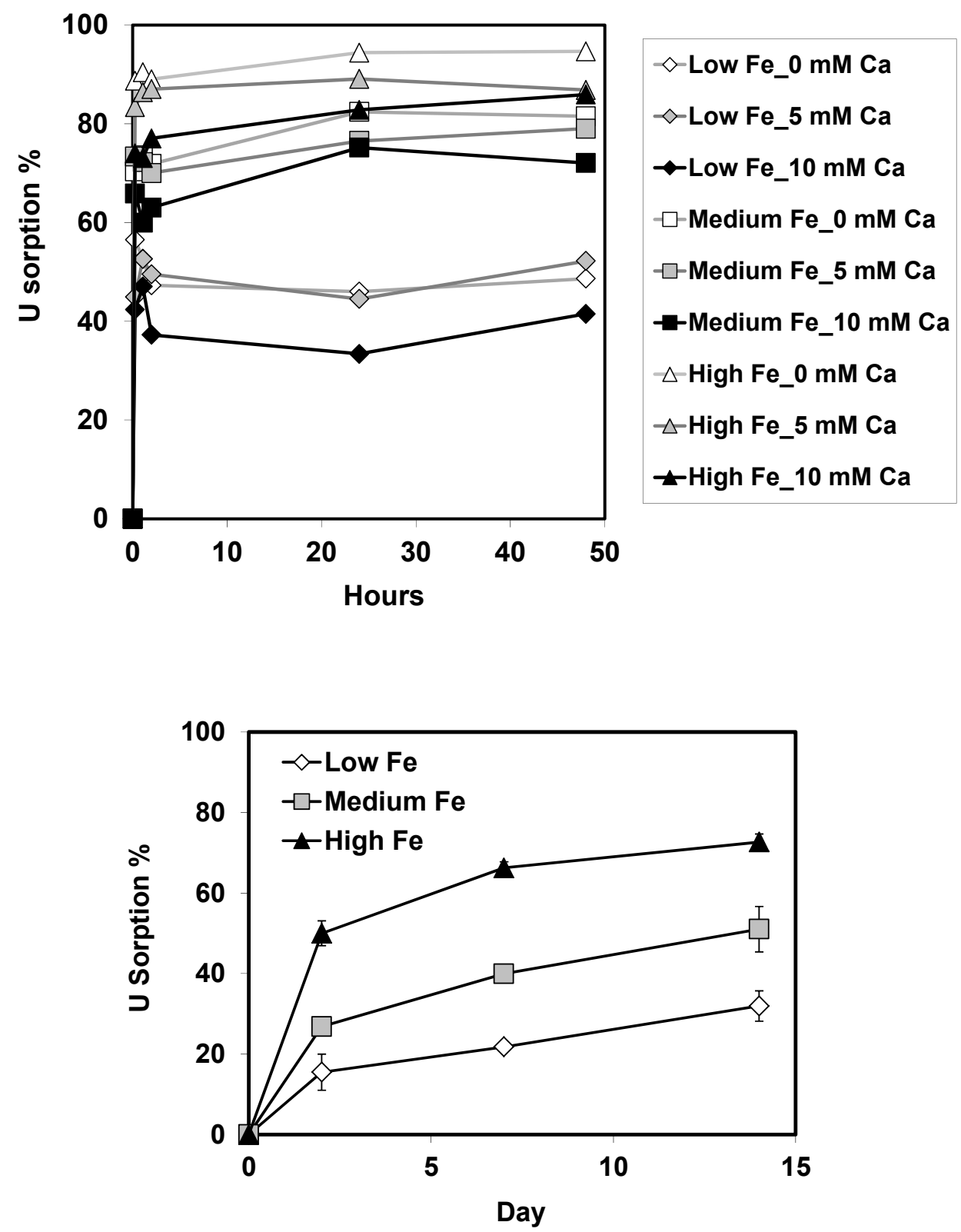

Fig. 5. Top: Sorption kinetics of $95 \mu \mathrm{M}$ U(VI) to ORFRC soils $(1 \mathrm{~g})$ with various Fe(III) oxide content in $0.1 \mathrm{M} \mathrm{NaNO}_{3}$ solution $(10 \mathrm{~mL})$ containing $1 \mathrm{mM} \mathrm{HCO}_{3}{ }^{-}$and a range of $\mathrm{Ca}^{2+}(0,5$, and $10 \mathrm{mM}$ ) at equilibrium $\mathrm{pH}$ of $\sim 6.5-7.0$ for 48 hours. Bottom: Sorption kinetics of $50 \mu \mathrm{M} \mathrm{U}(\mathrm{VI})$ to ORFRC soils $(1 \mathrm{~g})$ in $0.1 \mathrm{M} \mathrm{NaNO}_{3}$ solution $(10 \mathrm{~mL})$ containing $2.5 \mathrm{mM} \mathrm{Ca}^{2+}$ and $5 \mathrm{mM}$ $\mathrm{HCO}_{3}{ }^{-}$at equilibrium $\mathrm{pH}$ of $\sim 6.5-7.0$ for 2 weeks. Error bars represent standard deviation of replicates $(\mathrm{N}=2)$. 

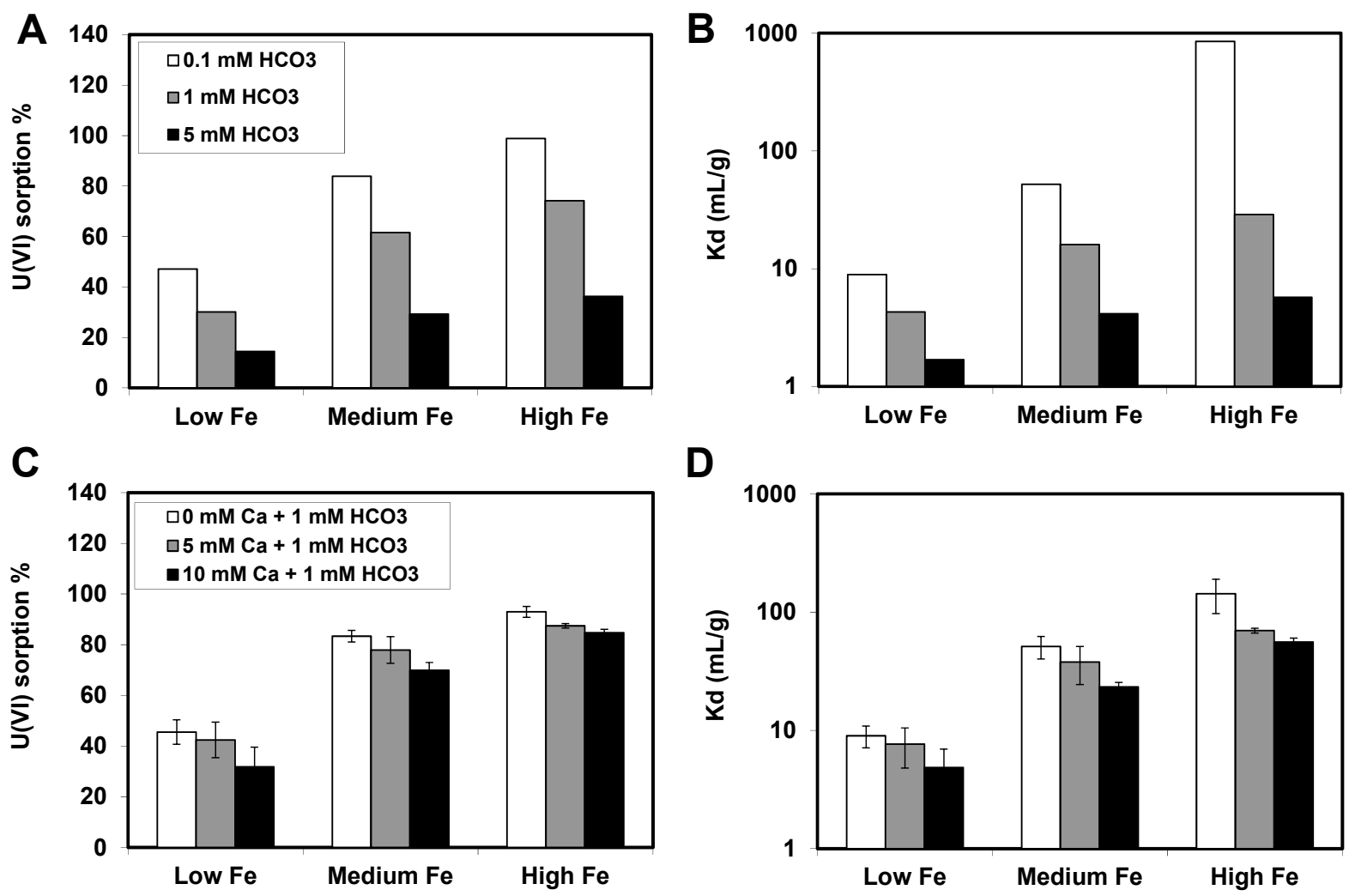

Fig. 6. U(VI) sorption to the low, medium, and high Fe(III) soils at circumneutral $\mathrm{pH}$ of $\sim 6.5-7.0$ at various $\mathrm{HCO}_{3}^{-}$and $\mathrm{Ca}^{2+}$ concentration. $\mathbf{A}$ and $\mathbf{B}$ : Sorption percentage and distribution coefficient (Kd) of $90 \mu \mathrm{M} \mathrm{U}(\mathrm{VI})$ in $0.1 \mathrm{M} \mathrm{NaNO}_{3}$ solution containing $0.1,1$, or $5 \mathrm{mM} \mathrm{HCO}_{3}{ }^{-}$for 2 days. C and D: Sorption percentage and distribution coefficient (Kd) of $95 \mu \mathrm{M} U(\mathrm{VI})$ in $0.1 \mathrm{M}$ $\mathrm{NaNO}_{3}$ solution containing $1 \mathrm{mM} \mathrm{HCO}_{3}^{-}$with 0,5 or $10 \mathrm{mM} \mathrm{Ca}^{2+}$ for 7 days. Error bars represent standard deviation of replicates $(\mathrm{N}=3)$. 

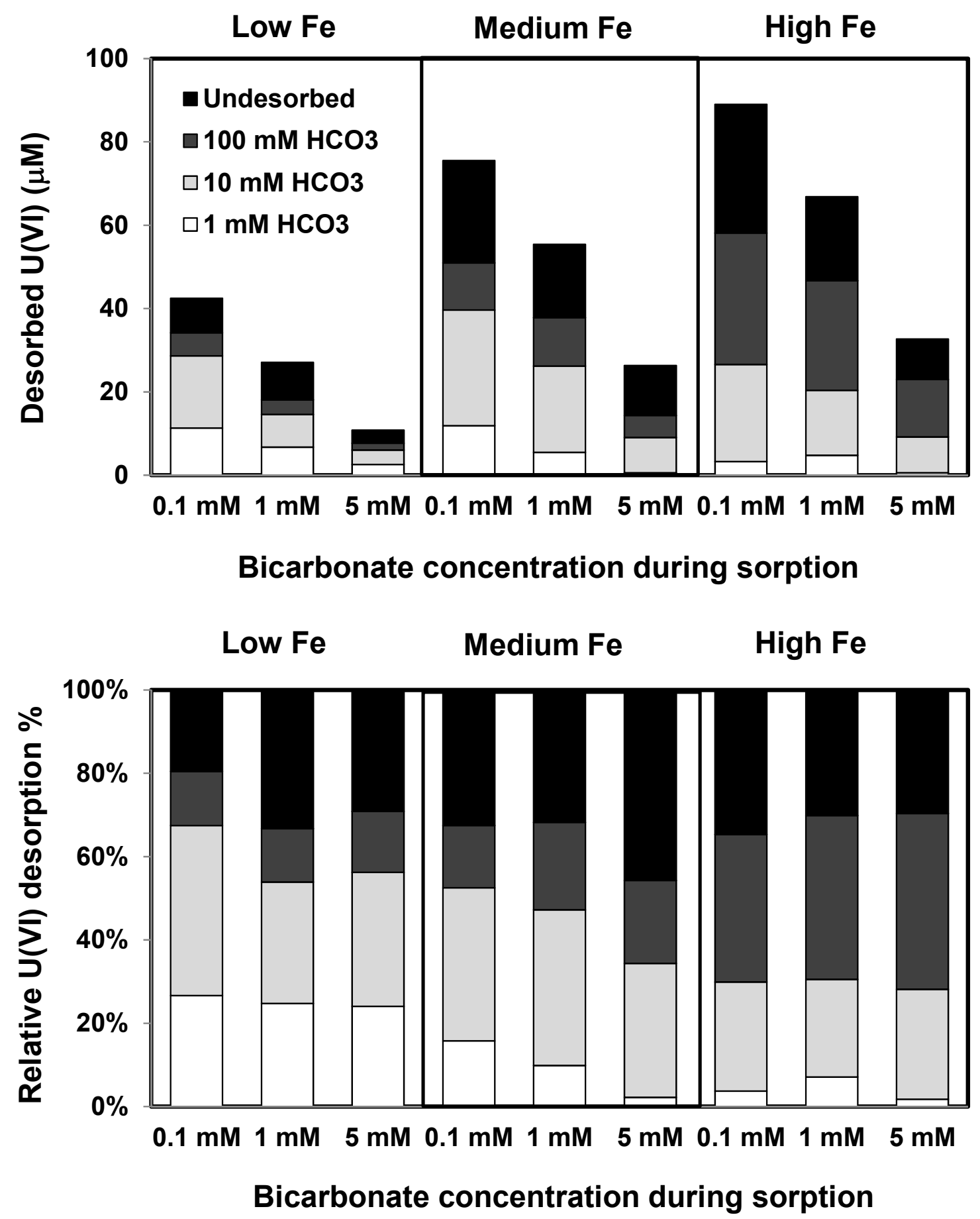

Fig. 7. U(VI) desorption from the low, medium, and high Fe(III) subsoils by sequential extraction with $1,10,100 \mathrm{mM} \mathrm{NaHCO}_{3}$ after sorption of $90 \mu \mathrm{M} \mathrm{U}(\mathrm{VI})$ in $0.1 \mathrm{M} \mathrm{NaNO}_{3}$ solution containing $0.1,1$, and $5 \mathrm{mM} \mathrm{HCO}_{3}{ }^{-}$. Each extraction was conducted for $24 \mathrm{hrs}$. 

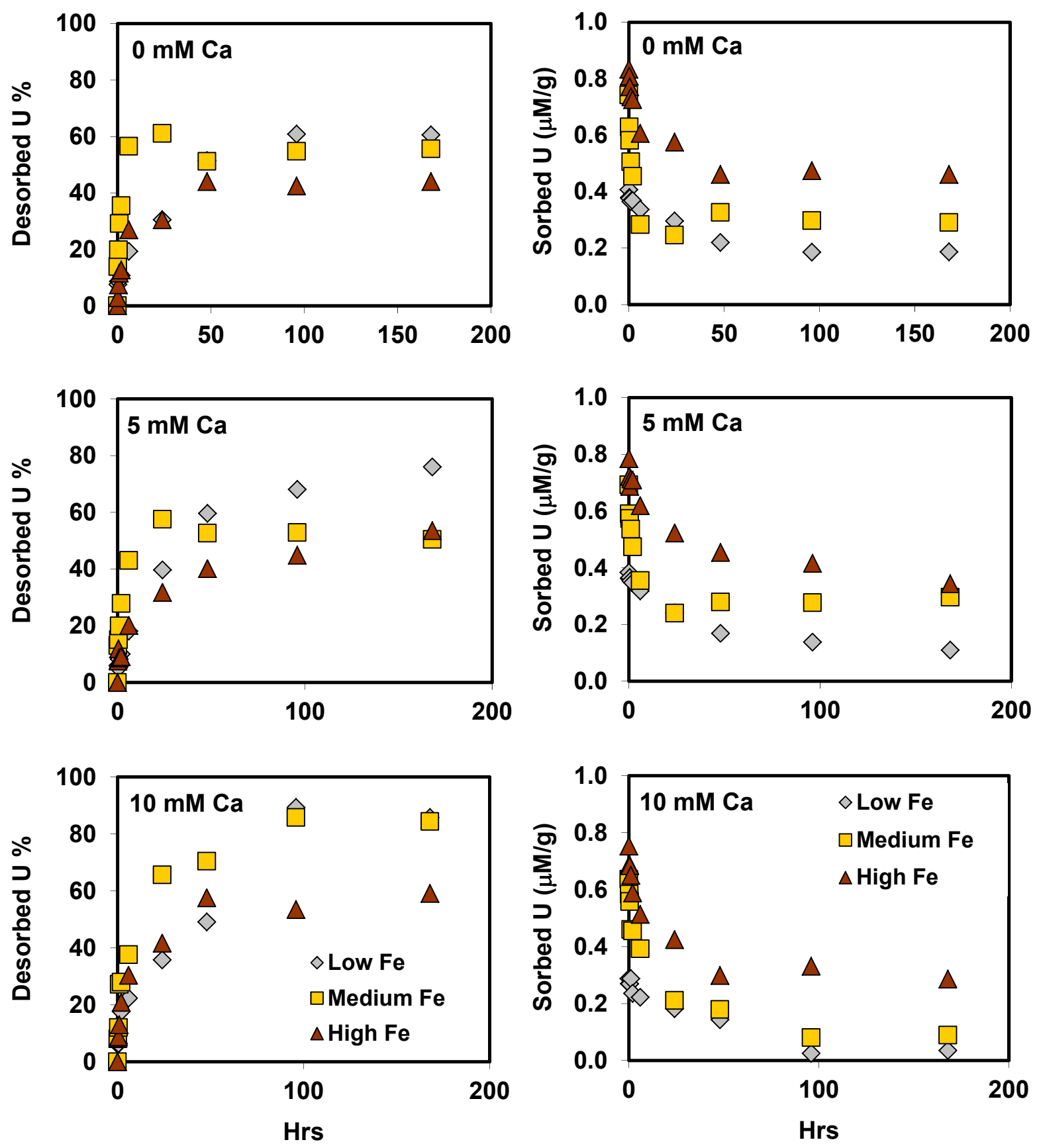

Fig. 8. Desorption kinetics of U(VI) (left) and U(VI) remaining on the solid phase (right) during 1-week extraction with $10 \mathrm{mM} \mathrm{NaHCO}_{3}$. The soils were exposed to $95 \mu \mathrm{M} \mathrm{U}(\mathrm{VI})$ in $0.1 \mathrm{M}$ $\mathrm{NaNO}_{3}$ solution containing $1 \mathrm{mM} \mathrm{HCO}_{3}^{-}$with 0,5 , or $10 \mathrm{mM} \mathrm{Ca}^{2+}$ for one week prior to conduction of the desorption experiment. 